\title{
The implications of the research literature on learning styles for the design of instructional material
}

\author{
Catherine McLoughlin \\ University of New England
}

\begin{abstract}
An enduring question for educational research is the effect of individual differences on the efficacy of learning. Aspects of individual differences that have been much explored relate to differences in learning styles, strategies and conceptions of learning. Such differences present a profound challenge for instructional designers, as research has shown that the quality of learning material is enhanced if the material is designed to take into account learners' individual learning styles (Rasmussen, 1998; Riding $\mathcal{E}$ Grimley, 1999). In the context of the present research, learning style is taken to mean a consistent or habitual of mode of acquiring or imparting knowledge through study, experience or teaching (Beishuizen $\mathcal{E}$ Stoutjesdijk, 1999). The purpose of this article is to propose ways in which individual differences can be accommodated when designing selfinstructional learning materials in print for distance learners. It is advocated that instructional designers turn to research on learning styles to inform the design of adaptive learning material. Kolb's (1984) learning cycle and associated learning styles are described with a view to providing instructional design guidelines which accommodate (i) each stage of the learning cycle (ii) individual differences between learners in processing and presenting information. Examples of learning activities for each stage of the learning cycle are provided from a tertiary bridging course for adult learners. It is recommended that in designing for a diverse student body, the research literature on learning styles can provide insights that have the potential to improve instructional design.
\end{abstract}

\section{Introduction}

In open and flexible learning contexts, instructional materials have the capacity to cater for individual needs while enabling collaborative forms of learning. At the outset, when designing materials for a given group of learners, instructional designers typically carry out a needs analysis or profile of the learners in order to ascertain the prior knowledge, motives, background interests, attitudes and experiences of learners. The rationale for such investigations is that individual dispositions will somehow affect and often influence learners' readiness to gain from the instruction that is 
offered, and influence academic progress. Instructional designers customarily acknowledge individual differences in their designs and often plan to adapt instruction to the needs of individual learners. Instructional practice and information gained from such needs analyses enables the design of learning resources tailored closely to the needs of the learners.

However, the reality is that in many institutional contexts, the pressure of student numbers and scarcity of resources limit the scope of learner needs analyses. Instructional material often remains fixed, unvaried and static, adaptive to individual needs in only minor ways, if at all. Students are expected to fit into the system and to cope as best they can. High rates of attrition in distance learning settings are not uncommon, and the research suggests that epistemological factors such as impediments in information presentation and the perceived difficulty of content are salient factors leading to non-persistence (Morgan \& Tam, 1999; Ozga \& Sukhnanden, 1998). For instructional designers, an often neglected source of information on individual differences is the growing body of research on learning styles and strategies, which explains how individuals learn, process new knowledge and represent information. It is suggested that current research literature in the area of learning styles and strategies can provide instructional designers with insights into individual differences in learning and performance that can be factored into the design process.

\section{Learning styles: Categories, concepts and frameworks}

The learning style literature presents a confusing array of terms that are similar, yet quite distinct. Clarification of these is essential to an understanding of issues in education and training. One of the clearest classifications of terms is presented by Curry (1991) and Riding \& Cheema, 1991). Definitions of these terms are provided in Table 1.

The most salient dimension that differentiates the terms learning style, learning strategy, learning preferences and cognitive style is the degree to which they can be observed and articulated. For example, learning preferences are easily expressed "I really like working in groups, I just can't come to terms with new concepts unless I discuss them with others". Similarly, learning and cognitive strategies may be inferred by observing students or by allowing them to think aloud as they study.

Cognitive styles and learning styles on the other hand, are often assessed using a questionnaire or psychometric test. Various instruments have been developed for this purpose including the Honey and Mumford's (1992) learning styles questionnaire (LSQ) or Riding's (1991) Cognitive 
Styles Analysis (CSA). Much of the research on learning styles has been conducted by psychologists using psychometric tests of personality and intelligence, and the results used to design training in management and educational settings (eg., Allinson \& Hayes, 1994; 1988; Curry, 1991). Since the late 1970s there has been an increased focus on the applicability of learning styles research for learners in a range of educational settings, thus broadening the scope of research on individual differences. In the present study we distinguish between the cognitive-perceptual styles research (eg., Riding, 1991; Riding \& Douglas, 1993) and the learning centered tradition which focuses on approaches to studying (eg., Biggs, 1987; Watkins, 1998). Each of these strands will be discussed in relation to its contribution to designing learning materials.

Table 1: Definitions of similar terms relating to learning styles

\begin{tabular}{|l|l|}
\hline Term & Explanation \\
\hline $\begin{array}{l}\text { Learning } \\
\text { preference }\end{array}$ & $\begin{array}{l}\text { favouring one method of teaching over } \\
\text { another }\end{array}$ \\
\hline $\begin{array}{l}\text { Learning } \\
\text { strategy }\end{array}$ & $\begin{array}{l}\text { adopting a plan action in the acquisition of } \\
\text { knowledge, skills or attitudes }\end{array}$ \\
\hline Learning style & $\begin{array}{l}\text { adopting a habitual and distinct mode of } \\
\text { acquiring knowledge }\end{array}$ \\
\hline $\begin{array}{l}\text { Cognitive } \\
\text { strategy }\end{array}$ & $\begin{array}{l}\text { adopting a plan of action in the process of } \\
\text { organising and processing information }\end{array}$ \\
\hline Cognitive style & $\begin{array}{l}\text { a systematic and habitual mode of organising } \\
\text { and processing information }\end{array}$ \\
\hline
\end{tabular}

\section{Cognitive-perceptual differences in learning: Psychological research}

Early work on individual differences among psychologists was triggered according to Grigerenko \& Sternberg (1995), by a sense of frustration with the limitations of research on ability and intelligence. Research had failed to identify processes underlying individual differences in learning and as a result there was increased focus on cognitive and perceptual functioning. This resulted in the identification of several styles or abilities and dimensions of cognitive and perceptual processing (Witkin, 1977; Pask, 1976; Allinson \& Hayes, 1994). Many researchers in this tradition see learning style as a coherent whole that students employ in their learning orientation, which may be attributed to underlying differences in personality and cognitive functioning (eg., Witkin et al, 1971; Riding, 1991). 
Psychologists investigating individual differences have defined learning style as a tendency to approach cognitive tasks with a preferred strategy or set of strategies, corresponding with a preferred mental set (Riding \& Rayner, 1998). Riding \& Cheema (1991), having surveyed a number of learning style constructs, propose a broad categorisation of two cognitive style families that relate to how people process and represent information. This categorisation is useful as it suggests that learners differ in terms of two fundamental dimensions:

a. Wholist-analytical: This dimension describes how individual process information. Analysts tend to process information into component parts, while wholists prefer to keep a global view of the topic. The wholistic-analytic approach is similar to that proposed by Pask (1976) as serialism and holism. Serialism is the step by step acquisition of material, while wholism is an exploratory approach where information is first understood as a 'big picture' or overview and then broken down into smaller chunks.

b. Verbaliser-imager: This dimension describes how individuals represent information during recall. Thus, verbalisers tend to present information in words, while imagers tend to present information in pictorial form.

Each of these aspects of cognitive style is a continuum, and each is independent of each other. It is proposed that these dimensions of cognitive style can be effectively applied to the design of instructional materials so that comprehension is facilitated by matching mode of presentation to cognitive style (eg., Riding \& Grimley, 1999).

\section{Learning styles and approaches: The learning centered tradition}

The learning centered approach can be identified as a distinct stream of style-based research that differs from the psychological orientation of cognitive-perceptual research. This approach has, according to Riding \& Rayner (1998), been motivated by educationists addressing the diversity of the environment in which learning takes place, and driven by processbased concerns relating to meeting individual differences and learning needs. The focus has shifted from concentrating on the constructs of intelligence and processing of information to an increased interest in learners' active response to the learning task and to the learning environment. 
The learning centered tradition has grown out of process-based models of learning such as:

- the learning process as a form of experiential learning (Kolb, 1984)

- learners' orientations to learning (Entwistle 1981; Biggs, 1979)

- cognitive skills and strategy development (Keefe \& Monk, 1986).

This stream of research on learning style shows that learners are dynamic and open to adaptation according to the particular context of learning. Criticism has been voiced about the learning-centered tradition of research on learning styles, on the basis that it represents an uncertain relationship between learning style and cognition and that concepts are poorly defined and used loosely (Riding \& Rayner, 1998). However, the strength of the learning-centered tradition is that it attempts to contextualise and operationalise the construct of 'learning styles' and to apply the insights gained to improving pedagogical practice. It has therefore grown in ascendancy in recent years. To further differentiate the learner-centered research approach, much of it has been carried out in Europe and has focused on approaches to studying (Entwistle \& Ramsden, 1983; Biggs, 1979; Trigwell \& Prosser, 1999; Watkins 1982). How the learner performs in the learning context remains the prime focus and characterises much recent research carried out on learning approaches among tertiary students (Busato, Prins et al, 1998; Cleminson et al 1994; Ellis, 1996; Evans \& Honour 1997; Watkins, 1998).

What has been most productive in the learning-centered tradition has been the additional insight gained about individual differences and strategies that emerge while learners are engaged in the process of learning. Individuals tend to develop learning strategies in order to deal with learning materials and therefore learning strategies can be regarded as cognitive tools, which enable learners to complete tasks and solve problems. By relating the research on learning strategies to the design of learning environments it is possible to investigate how learners approach their learning, how they perceive of themselves as learners and what they value in the learning experience (eg., Biggs, 1987; Entwistle \& Ramsden, 1983).

\section{Rationale for applying learning styles research to design of courseware}

Instructional design decisions need to be based not only on desired learning outcomes, but also on motivational, cognitive and volitional views of learning from the learners' perspective. This view of the learning 
process takes into account contextual and learner variables, and leads to a constructivist, learner-responsive view of materials design (Honebein, Duffy \& Fishman, 1993). As expressed by these authors, the learner context is crucial in the design process:

Stated simply, the context is not just an external context imposed by somebody else. It is also an internal context- the frame of reference or point of application that the learner generates (envisions). The learners (or readers) bring their own framework to the task. They have real world problems they are trying to solve and they read the text with those problems in mind. Hence the reader is cognitively problem solving in the area of application while reading the text. What information is attended to, how the information is organised and what personal knowledge is combined with the information all revolves around.... those contexts of application the reader imposes (Honebein et al., 1993: 93).

Learning styles research is of enormous significance with respect to establishing the learners' contexts of application and learning, so that these understandings can be brought into the design process.

Rowntree (1992) argues persuasively that developers need to take into account the research on learning styles, and to design materials for flexibility, diversity and balance. In a comprehensive review of literature, Richardson (1994) also concludes that higher education requires students to comprehend, and not merely to reproduce ideas and that acknowledging different approaches to learning enables authentic tasks to be created which are responsive to learner needs. In designing a learning task there is also an increased emphasis on productive as opposed to reproductive learning activities. For example, learners are required to solve problems, produce arguments and evaluate their own work and that of others. These productive and creative activities have signaled a shift in emphasis in higher education from reproductive to higher order learning activities and an emphasis on meaning-directed and investigative styles of learning (Trigwell \& Prosser, 1999). Such an approach necessitates taking into account differences in prior knowledge and a greater understanding of learning processes in which learners are participants in knowledge creation, not mere receptors of inert knowledge. Salomon \& Globerson (1987) maintain that mindfulness in learning involves intentional purposeful employment of non-automatic cognitive processes addressed to the task at hand. By enabling learners to have access to resources tailored to their own learning styles and instructional procedures, tutors can foster such higher order learning outcomes. 
In the United Kingdom, the Dearing report Higher Education in the Learning Society has endorsed learner-centered approaches and emphasises that learners should come to know their own learning styles. For learning tasks, they state that : an effective strategy is to guide and enable learners to be effective learners to understand their own learning styles and to manage their own learning. (Dearing, 1997: 24). Jonassen \& Wang (1993) concluded that merely providing content and information and showing learners structural relationships is not sufficient for higher cognitive performance. They conclude that "what matters most is the construction of personally relevant knowledge structures" (p. 7). This means that learners must be able to engage with the learning materials at varying levels and depths and be capable of accessing resources, which match or accommodate their learning preferences. This review of literature presents substantial evidence in favour of considering learning styles research when developing instructional materials.

Despite this evidence, the research is divided in its application of learning styles research to the development and design of instructional materials. On the one hand, some maintain that learning improves when learning styles are taken into account (eg., Riding \& Rayner, 1995; Riding \& Douglas, 1993). For example, Claxton \& Murrell (1987: 2) remark that "consideration of styles is one way to help faculty and administrators think more deeply about their roles and the organisational culture in which they carry out their work". Others favor extending or changing learners' cognitive systems or approaches to learning through adaptive, intelligent use of computer courseware and learning materials (Jonassen, 1988). In either case, it can be argued that both strands of learning styles research provide a wealth of insight into individual differences and orientations to learning that can be translated into instructional design.

\section{Theoretical framework: Kolb's learning cycle}

For the purpose of the present study, it was decided to apply a widely used model of the learning process derived from the learner-centred strand of research on learning styles as the basis for design of print-based learning materials in a tertiary context, and to combine this with other information gained about the target learners. Kolb's theory of experiential learning (Kolb, 1984) was used a starting point because of its consistency with stages of cognitive growth and development. The core of the theory is that learners progress through a learning cycle in which experience leads to observation and reflection, which then leads to concept formation (Figure 1). 


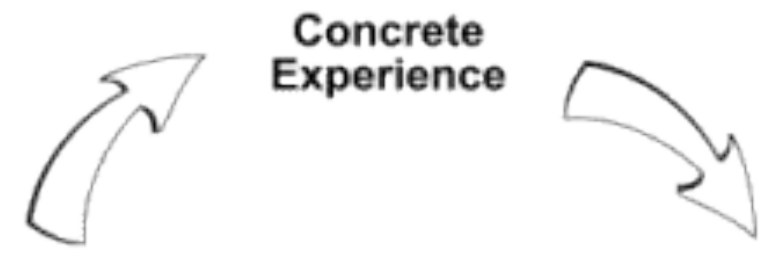

\section{Active \\ Experimentation}

\section{Reflective Observation}

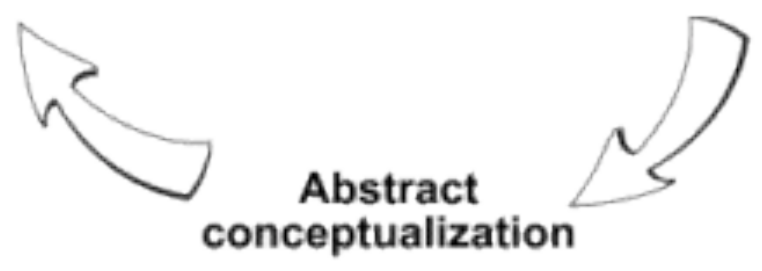

Figure 1: Stages of the learning cycle according to Kolb, 1984

The development of concepts in turn leads to new experiences and further experimentation, in cyclic fashion. Effective learners tend to proceed through all four stages but may develop dominance in one domain. Kolb's theory was adopted for the present study because it has been found to be successfully implemented in adult learning contexts where experiential learning is an appropriate pedagogy (Mulligan \& Griffin, 1992). Later research conducted by Honey \& Mumford $(1986,1992)$ modified Kolb's cycle and suggested four learning styles corresponding to each of the stages:

- activists: those who like new experiences and tackling new problems and quickly go on to new tasks to ensure novelty;

- pragmatists: those who like to apply new ideas immediately;

- reflectors: those who like consider all the aspects and angles before making a decision;

- theorists: those who integrate their observations into conceptual models.

Thus, Kolb's model of the learning process, based on a four-phase model is associated with four modes of learning characterised by the terms activists, reflectors, theorists and pragmatists (Figure 2). 


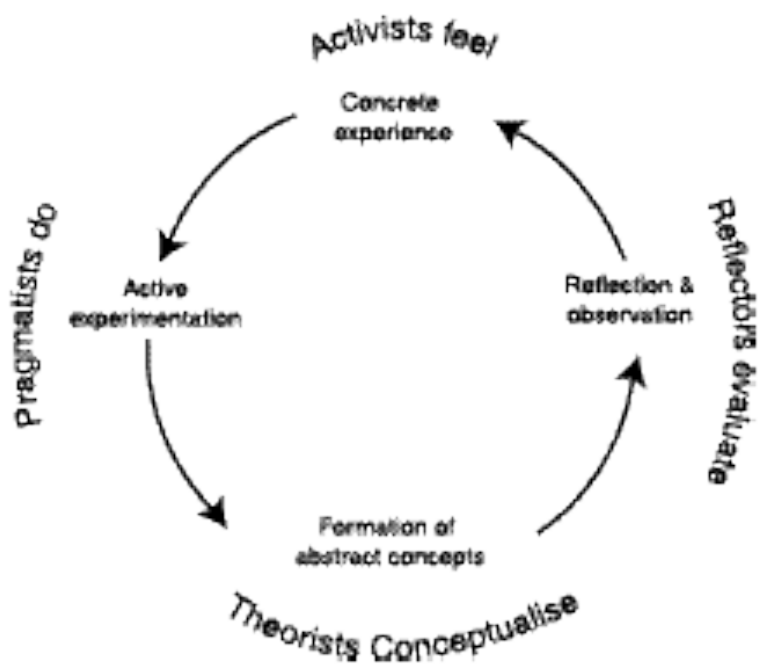

Figure 2: Learning styles associated with the learning cycle

In a later reworking of the learning cycle model, Kolb, Rubin \& Osland (1995) designed a 'floor map' exercise that enabled learners to identify their own learning profile. It was found that many learners have attributes that characterise all stages in the learning cycle and can demonstrate eclecticism in their capacity for concrete experience, formation of abstract concepts, active experimentation, reflection and observation.

According to educationists, the experiential learning model offers an excellent framework for designing, developing and delivering diverse learning experiences for adults, and offers instructional designers a tool for planning and designing learning activities (Rowntree, 1992; Tennant, 1988; Mulligan \& Griffin, 1992). For instance, reflection and conceptualisation on experience or on a learning event may lead to the forms of higher order thinking that enable learners to challenge and revise ideas, and thus engage in goal oriented, on-going learning (Anderson \& McMillan, 1992; Simons, 1992).

\section{The effect of learning styles on academic performance}

What evidence is there that individual differences in learning styles can affect performance in learning settings? Much empirical research signals that learning styles can hinder or enhance academic performance in 
several respects (Riding \& Grimley, 1999; Ross \& Schultz, 1999), although little research has been done on the relationship between instructional design of learning materials and learning styles.

Earlier, we described the two dimensions of cognitive style proposed by Riding \& Cheema (1991): the wholist-analytic and the verbaliser-imager. In support of these dimensions, studies conducted with students who were given a text comprehension task found that imagers learn better when information is presented in text-plus picture mode rather than in a wholly verbal mode (Cyrs, 1997; Jeung, Chandler \& Sweller, 1997). The additional visualisation afforded provides explanation that assists in comprehension (Riding \& Douglas, 1993). These findings indicate that for imagers, learning performance suffers when information is presented only in textual mode. Imagers also prefer to use diagrams to present information during recall. In recent study on learning differences with multimedia materials, Riding \& Grimley (1999: 47) found that "...style interacts with the structure of the materials in affecting learning... (it) affects both performance and preference in terms of mode of presentation and also interacts with the structure of material in influencing learning".

Other research on learning styles and achievement have shown that teaching students how to learn and how to monitor and manage their own learning styles is crucial to academic success (Matthews, 1991; Atkinson, 1998; Biggs \& Moore, 1993).

\section{Designing learning materials: a procedural approach to integrating learning styles research into instructional materials}

In the context of the study, a decision was made to apply the learning cycle of experiential learning (Kolb, 1984) in the design of learning tasks for a group of pre-tertiary students undertaking a bridging course into university called Learning Pathways. The unit of study for distance learners focussed on tertiary learning skills and was offered in print-based form for distance learners. It was hypothesised that the instructional design process would benefit by balancing the learning tasks and activities so that they would accommodate all learners by taking into account each stage of Kolb's learning cycle. In addition, it was intended to cater for learner differences by presenting information not only in text-based form, but also through visuals. Rather than testing or assisting learners prior to 
learning, it was decided to design the materials for maximum flexibility and diversity by developing tasks and activities which activated the various stages of Kolb's learning cycle. In addition, Riding and Cheema's (1991) verbaliser-imager, wholist-analyst dimensions were utilised in the design and presentation of learning resources.

The application of Kolb's learning cycle to design of learning activities utilised Collis' (1998) approach to designing an adaptation within a course module (see Figure 3). The academic unit was intended to cater to the learning needs of individuals by balancing task design to ensure that it encompassed:

- a range of activities to help learners to cope with each stage of the learning cycle;

- alternative tasks and activities to cater to individual needs;

- complementary modes of information presentation.

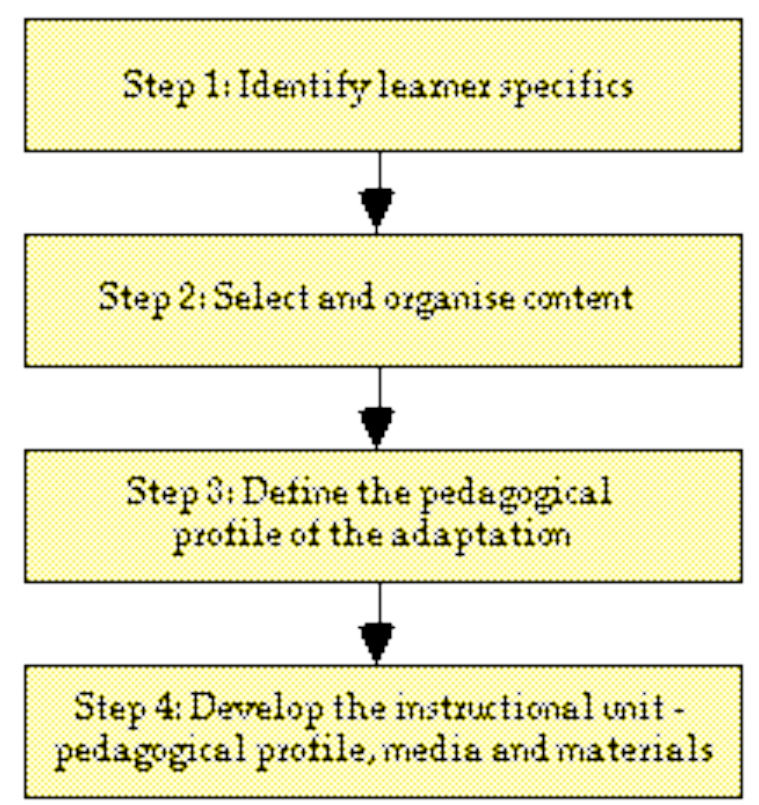

Figure 3: Steps in designing an adaptation within a learning module

These design guidelines were based on Kolb's experiential learning cycle and applied to a unit which aimed to develop learning skills for university and to prepare students for independent study. Applying the 
four stages of the learning cycle led to the development of a range of activities to enable students to build on concrete experience, to reflect on present and prior learning, to abstract from experience and to apply recently learnt content to new tasks and situations.

Learning activities were designed with a strong focus on metacognition and problem solving. Throughout the unit, students were confronted with situations and contexts which were problematic and in need of development, for example their own study skills and management strategies. Through inquiry into how others might approach tasks and by comparing this with their own situation, learners reflected on aspects of their situation that required change. Reflection and evaluation then led to action, and the learners created an improved study plan in which goals were identified.

Table 2: Design of learning tasks to match the learning cycle

\begin{tabular}{|l|l|l|}
\hline $\begin{array}{l}\text { Stage of learning } \\
\text { cycle }\end{array}$ & Learning method & Learning activities \\
\hline $\begin{array}{l}\text { Concrete } \\
\text { experience }\end{array}$ & $\begin{array}{l}\text { real life activities, use } \\
\text { of prior knowledge, } \\
\text { authentic activities }\end{array}$ & $\begin{array}{l}\text { Speak to a friend and find out how } \\
\text { they organise their study. Draw up or } \\
\text { create a timetable for your study that } \\
\text { fits in with your other obligations. } \\
\text { Discuss with a colleague }\end{array}$ \\
\hline Reflection & $\begin{array}{l}\text { Observation, self- } \\
\text { commentary }\end{array}$ & $\begin{array}{l}\text { How do you learn best? Think about a } \\
\text { situation in which you performed well } \\
\text { and record your thoughts in a journal }\end{array}$ \\
\hline Conceptualisation & $\begin{array}{l}\text { Analysis and } \\
\text { synthesis of concepts }\end{array}$ & $\begin{array}{l}\text { How would you describe yourself as a } \\
\text { learner? What are your strengths and } \\
\text { weaknesses? List the goals of your } \\
\text { study for this unit. }\end{array}$ \\
\hline $\begin{array}{l}\text { Practical } \\
\text { application and } \\
\text { testing }\end{array}$ & $\begin{array}{l}\text { Application of } \\
\text { principles to practical } \\
\text { problems }\end{array}$ & $\begin{array}{l}\text { What time management strategies } \\
\text { could you apply to you own situation? } \\
\text { Which would be most suited to you? } \\
\text { What benefits might they bring? }\end{array}$ \\
\hline
\end{tabular}

Table 2 provides examples of learning activity design in microcosm that are consistent with the principles of experiential learning while accommodating learners at each stage of the learning cycle. The principles for the design of tasks within the unit of study, informed by Kolb's experiential learning model can summarised as follows:

- a self-directed approach where learners are given choice in selecting life events and experiences as the basis for learning;

- an active approach to content which enables learners to relate prior experiences to new learning tasks; 
- the application of inquiry and reflection;

- the provision of multiple and varied opportunities to experience and demonstrate understanding;

- the provision of ongoing feedback from peers and the teacher to support reflection.

Each of these principles can be accommodated in print materials by building in choice, flexibility and multiple modes of feedback and activity.

\section{Accommodating differences in processing and conceptualising information}

A further dimension of the design of learning tasks was to accommodate different modes of processing and conceptualising information. As described by Riding (1991) these contrasting styles are the wholistanlaytical and the verbaliser-imager modes of processing and conceptualising knowledge. These dimensions were considered in the layout and presentation of information for the print-based modules. It was anticipated that matching instruction to these cognitive styles would benefit all learners as it offered them both visual and text-based modes of accessing information. Other research supports this approach. For example, Cyrs (1997) suggests incorporating the following categories of graphic symbols:

- image related graphics: recognisable representations of an object;

- concept related graphics: graphics which stylise objects by removing details; and

- arbitrary graphics: abstract symbols which show relationships between ideas.

When designing Learning Pathways, the design and layout were compensatory, in the sense that they accommodated all learner differences by presenting information to match the two dimensions wholist-anlaytical and the verbaliser-imager. Table 3 summarises how the materials were designed and presented in dual mode so that:

- wholists could benefit from an analytic advance organiser showing the structure of content in terms of division into topics and subtopics;

- analytics could benefit from the inclusion of a holistic advance organiser giving an overview of the whole;

- imagers could benefit from presentation of the information in $a$ diagrammatic form; and 
- verbalisers could be supported in interpreting presentation in a textual mode with supplementary visual information.

Table 3: Forms of information presentation to match cognitive style

\begin{tabular}{|l|l|l|}
\hline Style & Learner characteristics & Text presentation offered \\
\hline Wholists & $\begin{array}{l}\text { Tend to see the situation as } \\
\text { a whole }\end{array}$ & $\begin{array}{l}\text { Advance organiser to indicate } \\
\text { parts and structure of material }\end{array}$ \\
\hline Analytic & See collection of parts & $\begin{array}{l}\text { Overview to provide a picture } \\
\text { of the whole }\end{array}$ \\
\hline Verbalisers & $\begin{array}{l}\text { Represent knowledge } \\
\text { verbally (speech \& text) }\end{array}$ & $\begin{array}{l}\text { Verbal versions of pictorial } \\
\text { material }\end{array}$ \\
\hline Imagers & $\begin{array}{l}\text { Represent knowledge } \\
\text { pictorially (images) }\end{array}$ & Pictorial form verbal material \\
\hline
\end{tabular}

\section{Complementary design: Possibilities and limitations}

This complementary design approach takes into account cognitive styles and preferences and provides information in dual mode throughout a unit of study to support learners in each modality. By presenting information in text forms and pictorially, students have the advantage of accessing ideas in dual mode, and may choose according to their own learning style preference. The graphic symbols offered learners multiple views on knowledge organisation, and provided hierarchical and nonhierarchical views of the material to be studied. For example, the diagram of note making (Figure 4) was provided at the beginning of a module on how and why to make notes, in which learners were introduced to the rationale, techniques and skills of note-making.

This advance organiser enabled learners to gain an overview of the content in advance, to orient them to key terms and concepts and to return to this organiser throughout their learning.

In summary the process of visual design involved presenting information in dual mode and integrating graphic modes of presentation. This enabled learners to access information in a presentation format that was congruent with their own learning style. 


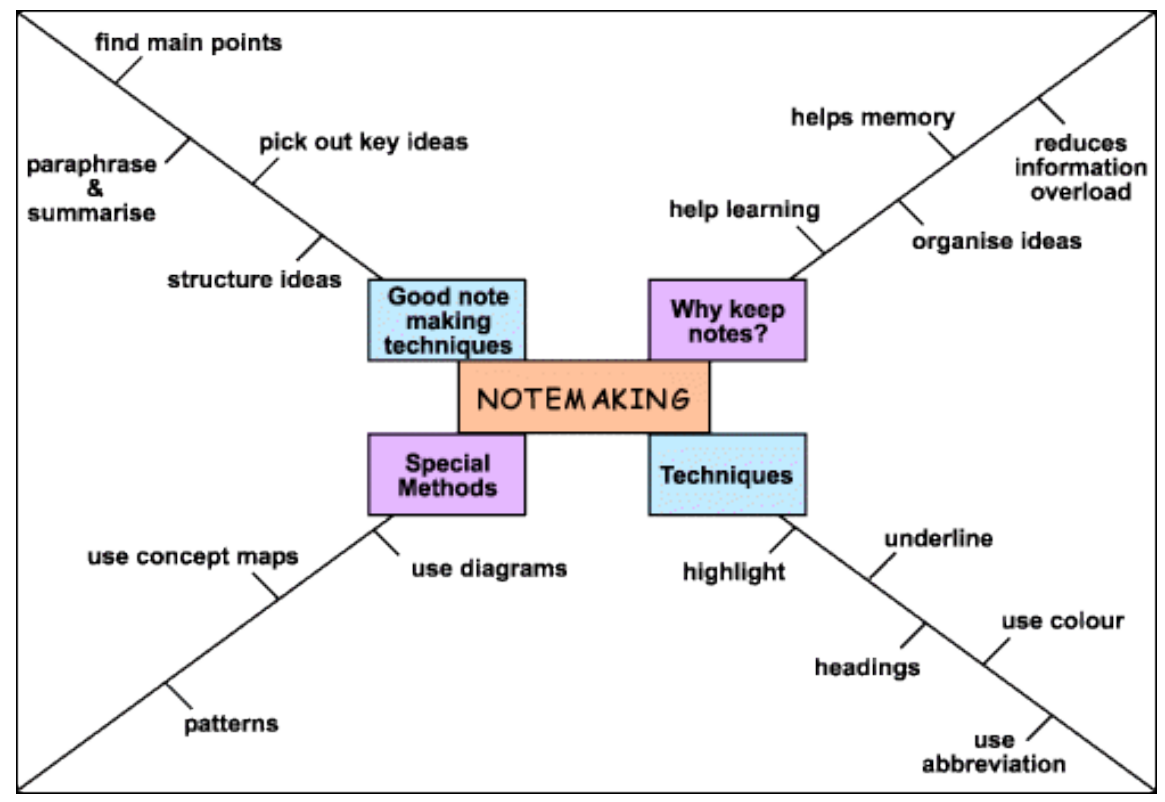

Figure 4: Advance organiser used to present a visual overview of learning material

\section{Summary and implications for design of instructional materials}

This article has described how Kolb's learning cycle and associated learning styles may be integrated into the design of learning materials to ensure that learner needs and preferences are accommodated. The decision was made based on extensive literature review of empirical research into the application of cognitive styles research to self-directed learning and achievement (Riding, 1997; Schmeck, 1988; Munro \& Howes, 1998; Riding \& Rayner, 1995; Beishuizen \& Stoutesdijk, 1999; SadlerSmith, 1997; Davidson \& Savenye, 1992).

It is suggested that Kolb's learning cycle (1984) can be combined with more conventional methods of instructional design of learning materials, such as events of instruction (Gagné, Briggs \& Wager, 1992). In addition, learning materials need to be evaluated in terms of learner responses and preferences so that instructional designers can learn about the needs and cognitive styles of learners and become more responsive to these needs in the design of materials. 
There has been a lack of confidence in learning styles research because inventories and definitions of learning styles vary and also because researchers in different traditions and contexts have addressed learning styles in unique ways (Murray-Harvey, 1994). This article has drawn attention to two traditions in the learning style research and how each can be applied to instructional design. One tradition of research derives from psychology and has been labeled as the 'cognitive-perceptual' tradition that focuses on different modes of processing and presenting information. Two principles cognitive styles are identified: wholist-analytic and verbaliser-imager (Riding \& Cheema, 1991). Research has found that individuals learn best when information is presented in ways that are congruent with their preferred styles (Riding \& Grimley, 1999). Applying this principle to the design of print-based learning materials requires balancing visual and textual modes of presentation.

The second stream of learning styles research has been labeled the 'learning-centered tradition', with a focus on approaches to learning, and conceptions of learning (Entwistle, 1981). Within the 'learning-centered' tradition, Kolb's (1984) experiential learning cycle is adopted as model for design of activities. The stages in the learning cycle are linked to Honey \& Mumford's (1992) four style differences, activists, reflectors, theorists and pragmatists. It is posited that every learner goes through this set of stages towards understanding. The learner may have experience or prior knowledge, which is activated through appropriate design of learning tasks. The stages of review, reflection and abstraction can be fostered through design of learning tasks. In the final stage, new knowledge is fully integrated into the learner's experiences and the cycle is complete. Honey (1989) claims that only a minority of learners have all four styles, and that most learners have the capacity to employ all four, but never have the opportunity. Course designers who aim to encompass all stage of the learning cycle are therefore not only catering for diversity, but also expanding the learning repertoire of learners by providing for contextual, experiential and theoretical elements of the learning process (Seden, 1994; Knapper, 1995; Anderson, 1992).

To promote improved design of instructional materials, knowledge about individual differences needs to be integrated and connected directly with the design process, so that instructional materials are not only flexible, but also supportive of diversity and capable of accommodating a wide range of learning styles. Further research into the application of Kolb's learning cycle in online environments for learning would provide interesting insights into how the model could be adapted or extended for hypermedia design. 
In conclusion, the literature on learning styles and individual differences provides a rich but largely untapped source of data for instructional designers. Consideration of this literature can lead to a greater understanding of learners' approaches to study, greater awareness of individual differences in learning and improved design to cater for diversity.

\section{References}

Allinson, J., \& Hayes, C. (1994). Cognitive style and its relevance for management practice. British Journal of Management, 5, 53-71.

Allinson, C. W., \& Hayes, J. (1988). The learning styles questionnaire: An alternative to Kolb's inventory? Journal of Management Studies, 25, 269-281.

Anderson, B., \& McMillan, M. (1992). Learning experiences for professional reality and responsibility. In J. Mulligan \& C. Griffin (Eds.), Empowerment through experiential learning (pp. 222-232). London: Kogan Page.

Atkinson, S. (1998). Cognitive style in the context of design and technology work. Educational Psychology, 18(2), 183-194.

Beishuizen, J. J., \& Stoutjesdijk, E. T. (1999). Study strategies in a computer assisted study environment. Learning and Instruction, 9(3), 281-301.

Biggs, J. B. (1987). Student approaches to learning and studying. New York: Plenum.

Biggs, J. B. (1979). Individual differences in study processes and the quality of learning outcomes. Higher Education, 8(381-394).

Biggs, J. B., \& Moore, P. J. (1993). The process of learning (3rd Edition ed.). Englewood Cliffs, N.J.: Prentice Hall.

Busato, V., Prins, F. J., Elshout, J., \& Hamaker, C. (1998). Learning styles: A cross sectional and longitudinal study in higher education. British Journal of Educational Psychology, 68, 427-441.

Claxton, C., \& Murrell, P. (1987). Learning styles: Implications for improving educational practices (Report no. 4). Texas: ASHE-ERIC.

Cleminson, K., Putnam, K., \& Bradford, S. (1994). Effects of learning styles and context on work-based learning. In G. Gibbs (Ed.), Improving student learning (pp. 359-371). Oxford: Oxonian Rewley Press.

Collis, B. (1998). Flexible learning and the design of instruction. British Journal of Educational Psychology, 29(1), 59-72.

Curry, L. (1991). Patterns of learning style across selected medical specialties. Educational Psychology, 11, 247-278.

Cyrs, T. (1997). Visual thinking: Let them see what you are saying. New directions for teaching and learning, 71(Fall), 27-32. 
Davidson, G. V., \& Savenye, W. S. (1992). How do learning styles relate to performance in a computer applications course? Journal of Research on Computing in Education, 24(1), 348-358.

Dearing, R. (1997). Higher education in the learning society: Report of the National Committee of Inquiry into higher education. London: HMSO \& NCIHE.

Ellis, A. E. (1996). Learning styles and hypermedia courseware design. In P. Carlson \& F. Makedon (Eds.), Proceedings of the 8th World Conference on Educational Multimedia and Hypermedia (Vol. 2, pp. 354-359). Charlottesville, VA.: Association for Advancement of Computing in Education (AACE).

Entwistle, N. (1981). Styles of learning and teaching. New York: John Wiley.

Entwistle, N. J., \& Ramsden, P. (1983). Understanding student learning. London: Crumb Helm.

Evans, B., \& Honour, L. (1997). Getting inside knowledge: The application of Entwistles's model of surface-deep processing in producing open learning materials. Educational Psychology, 17(1), 127-139.

Gagné, R. M., Briggs, L. J., \& Wager, W. W. (1992). Principles of instructional design. Orlando, FL.: Harcourt, Brace, Janovich.

Grigerenko, E. L., \& Sternberg, R. J. (1995). Thinking styles. In D. H. Saklofske \& M. Zeidner (Eds.), International handbook of personality and intelligence (pp. 205230). New York: Plenum Press.

Honey, P., \& Mumford, A. (1992). The manual of learning styles. Maidenhead: Peter Honey.

Honebein, P. C., Duffy, T. M., \& Fishman, B. J. (1993). Constructivism and the design of learning environments: Context and authentic activities for learning. In T. M. Duffy, J. Lowyck, D. H. Jonassen, \& T. M. Welsh (Eds.), Designing environments for constructive learning (pp. 87-107). Berlin: Springer-Verlag.

Jeung, H.-J., Chandler, P., \& Sweller, J. (1997). The role of visual indicators in dual sensory mode instruction. Educational Psychology, 17(3), 329-344.

Jonassen, D. (1988). Integrating learning strategies into courseware to facilitate deeper processing. In D. H. Jonassen (Eds.), Instructional designs for microcomputer courseware (pp. 151-182). Hillsdale, N.J.: Lawrence Erlbaum.

Jonassen, D. H., \& Wang, S. (1993). Acquiring structural knowledge from semantically structured hypertext. Journal of Computer-based Instruction, 20(1), $1-8$.

Keefe, J. W., \& Monk, J. S. (1986). Learning styles profile. Reston, VA: National Association of Secondary School Principals.

Knapper, C. K. (1995). Understanding student learning: Implications for instructional practice. In W. A. Wright (Ed.), Teaching improvement practices. Bolton. MA: Anker Publishing Company. 
Kolb, D. A. (1984). Experiential learning. Englewood Cliffs, N.J.: Prentice-Hall.

Kolb, D. A., Osland, J. S., \& Rubin, I. W. (1995). Organisational Behaviour: An experiential approach. Englewood Cliffs, N.J.: Prentice Hall.

Pask, G. (1976). Styles and strategies of learning. British Journal of Educational Psychology, 46, 128-48.

Matthews, D. B. (1991). The effects of learning styles on grades of first-year college students. Research in Higher Education, 32(3), 253-268.

Morgan, C. K., \& Tam, M. (1999). Unravelling the complexities of distance education student attrition. Distance Education, 20(1), 96-108.

Mulligan, J., \& Griffin, C. (1992). Empowerment through experiential learning. London: Kogan Page.

Munro, J. (1998). The effect of cognitive style on learning to write a letter of complaint. British Journal of Educational Psychology, 68, 243-254.

Murray-Harvey, R. (1994). Learning styles and approaches to learning: Distinguishing between concepts and instruments. British Journal of Educational Psychology, 64(3), 373-388.

Ozga, L., \& L. Sukhnandan, L. (1998). Undergraduate non-completion: Developing an explanatory model. Higher Educational Quarterly, 52(3), 316-333.

Prosser, M., \& Trigwell, K. (1999). Understanding learning and teaching: The experience of higher education. Buckingham: Open University Press.

Rasmussen, K. L. (1998). Hypermedia and learning styles: Can performance be influenced? Journal of Multimedia and Hypermedia, 7(4), 291-308.

Rayner, S., \& Riding, R. (1997). Towards a categorisation of cognitive styles and learning styles. Educational Psychology, 17(1), 5-27.

Richardson, J. T. E. (1994). Cultural specificity of approaches to studying in higher education. Higher Education, 27, 449-468.

Riding, R. J. (1991). Cognitive styles analysis. Birmingham: Learning and Training Technology.

Riding, R., \& Grimley, M. (1999). Cognitive style and learning from multimedia materials in 11-year children. British Journal of Educational Technology, 30(1), 4359.

Riding, R., \& Cheema, I. (1991). Cognitive styles: An overview and integration. Educational Psychology, 11(3 \& 4), 193-215.

Riding, R., \& Douglas, G. (1993). The effect of cognitive style and mode of presentation on learning performance. British Journal of Educational Psychology, 63, 297-307. 
Riding, R., \& Rayner, S. (1998). Cognitive styles and learning strategies. London: David Fulton Publishers.

Riding, R. J. (1997). On the nature of cognitive style. Educational Psychology, 17(2), 29-49.

Riding, R. J., \& Rayner, S. (1995). The information superhighway and individualised learning. Educational Psychology, 15(4), 365-378.

Ross, J. (1999). Can computer-aided instruction accommodate all learners equally? British Journal of Educational Technology, 30(1), 5-24.

Rowntree, D. (1992). Exploring open and distance learning materials. London: Kogan Page.

Sadler-Smith, E. (1997). 'Learning style': Frameworks and instruments. Educational Psychology, 17(1), 51-63.

Salomon, G., \& Globerson, T. (1987). Skills may not be enough: The role of mindfulness in learning and teaching. International Journal of Educational Research, 11(6), 623-627.

Sadler-Smith, E. (1997). Learning styles and instructional design. Innovations in Education and Training International, 33(4), 185-193.

Seden, M. R. (1994). Course design and student learning. In G. Gibbs (Ed.), Improving student learning (pp. 371-378). Oxford: Oxonian Rewley Press.

Schmeck, R. R. (1988). Learning strategies and learning styles. New York: Plenum Press.

Simons, P. R. J. (1992). Theories and principles of learning to learn. In A. Tuijman (Eds.), Learning across the lifespan (pp. 159-171). London: Pergamon Press.

Tennant, M. (1988). Psychology and adult learning. London: Routledge.

Watkins, D. (1982). Identifying the study process dimensions of Australian University students. Australian Journal of Educational Research, 26, 76-85.

Watkins, D. (1998). Assessing approaches to learning. In B. Dart \& G. BoultonLewis (Eds.), Teaching and Learning in Higher Education . Melbourne: ACER.

Witkin, H. A., Ottman, P. K., Raskin, E., \& Karp, S. A. (1971). A manual for the embedded figures test. Palo Alto, California: Consulting Psychologists Press.

Witkin, H. A., Moore, C. A., Goodenough, D. R., \& Cox, P. W. (1977). Field dependent and field independent cognitive styles and their educational implications. Review of Educational Research, 47, 1-64.

Dr. Catherine McLoughlin is Senior Lecturer in Higher Education in the Teaching and Learning Centre, University of New England, Armidale, NSW 2351. Email: mcloughlin@metz.une.edu.au Tel: +61 267732670 